\title{
SOLAR ENERGY SUPPORTED HYDROGEN PRODUCTION: A THEORETICAL CASE STUDY
}

\author{
${ }^{1}$ Ali ATES, ${ }^{2}$ Sacit Zendehdel SHEKARDASHT, ${ }^{3}$ Eyüb CANLI \\ 1,3Selcuk University, Department of Mechanical Engineering, Campus, Selcuklu, Konya, TURKEY \\ ${ }^{2}$ Selcuk University, Graduate School of Natural Sciences, Selcuklu, Konya, TURKEY \\ 1aates@selcuk.edu.tr, ${ }^{2}$ sajed.zendehdel@yahoo.com, ${ }^{3}$ ecanli@selcuk.edu.tr
}

(Geliş/Received: 20.04.2017; Kabul/Accepted in Revised Form: 19.06.2017)

\begin{abstract}
Hydrogen is an important energy vector and a strong candidate for energy storage. It will be a useful tool for storing intermittent energy sources such as sun. The main objective of this work is to assess a system harnessing solar energy in electrical form and store it as hydrogen by means of an electrolyzer for small scale consumers away from the grid such as rural areas by computer simulation. Hydrogen then can be consumed in a fuel cell in order to generate electricity. The electrical energy obtained from solar energy via photovoltaic panels was used in order to charge a battery first and then hydrogen was acquired by using aforementioned energy in the electrolysis of water. In the second stage, electricity is generated in a fuel cell by using the generated hydrogen. A theoretical analysis was done via computer software by solving the constituted mathematical model. Data containing monthly average insolation values of Konya City according to years were used in this model. Electrolyzer temperature and pressure values and efficiencies of the photovoltaic panels were used as the input parameters. General system efficiency and effectiveness, generated electricity and hydrogen amounts were obtained as the output parameters. Among all, temperature was found to be the most effective parameter according to the obtained results considering the generated hydrogen amount, system effectiveness and efficiency. A wide range of electrical power between $400 \mathrm{~W}$ and $1800 \mathrm{~W}$ can be harnessed from the PV part of the system. Hydrogen production in the other hand can be attained in the range of 120-130 g/month. Power curve of the fuel cell at the start up of the system yields a 0.001 seconds reaction time. The proposed system can be utilized in rural parts of Konya and climatically similar regions in the world.
\end{abstract}

Key Words: Electrolysis of water, Hydrogen fuel cell, Mathematical model, Photovoltaic.

\section{Güneş Enerjisi Destekli Hidrojen Üretimi: Teorik Bir Vaka Çalışması}

ÖZ: Hidrojen önemli bir enerji taşıyıcısıdır ve enerji depolanması için güçlü bir adaydır. Güneş gibi kesikli bir enerji kaynağının depolanması için kullanışlı bir araç olacaktır. Bu çalışmanın ana amacı bir bilgisayar simulasyonu vasıtası ile kırsal kesimler gibi elektrik şebekesinden uzaktaki küçük ölçekli tüketiciler için güneş enerjisinin elektriksel formda elde edildiği ve saha sonra bir elektrolizer ile hidrojen şeklinde depolandı̆̆ bir sistemi değerlendirmektir. Hidrojen daha sonra tekrar elektrik üretmek için bir yakıt hücresinde tüketilebilir. Önce güneş enerjisinden fotovoltaik paneller aracılığı ile elde edilen enerji ile bir akü şarj edilmiş ve bu enerji suyun elektrolizi işleminde kullanılmak suretiyle hidrojen elde edilmiştir. İkinci aşamada elde edilen hidrojen bir yakıt hücresinde kullanılarak elektrik enerjisi elde edilmiştir. Oluşturulan matematiksel model, geliştirilen bilgisayar programı vasıtası ile çözümlenerek teorik bir inceleme yapılmıştır. Bu modelde Konya iline ait güneş ışınımının yıllara göre aylık ortalama değerlerine ait veriler kullanılmıştır. Giriş parametreleri olarak elektrolizör sıcaklığı, elektroliz basınç değerleri ve fotovoltaik panellerin verimi kullanılmıştır. Genel sistem verim ve etkenliği, üretilen elektrik ve hidrojen miktarları ise çıkış parametreleri olarak belirlenmiştir. Elde edilen sonuçlara göre, gerek üretilen hidrojen miktarı yönünden, gerekse sistemin etkenliği ve verimi yönünden, giriş parametreleri arasında en etkili bileşenin sıcaklık olduğu görülmüştür. Sistemin fotovoltaik kısmından $400 \mathrm{~W}$ ile $1800 \mathrm{~W}$ arasından geniş bir yelpazede elektrik enerjisi elde edilebilmektedir. Diğer yandan aylık hidrojen üretimi 120-130 g/ay aralığındadır. Yakıt pilinin güç eğrisi, 0.001 saniye cevap süresi ortaya koymuştur. Önerilen sistem Konya'da ve dünyada benzer iklim özelliklerine sahip başka bölgelerde kullanılabilir. 


\section{INTRODUCTION}

Renewable energy is not only indispensable but also a new investment way for the small scale investors. In the sectors such as agriculture, mining, industry and service, off grid renewable energy systems have been emerging. For instance, photovoltaic (PV) systems are gaining more and more importance in small scale applications. A comprehensive information compilation about PV panels can be found in the report of Sayın and Koç (2011). With the existence of grid support, these systems work as they are desired. However when the grid is not accessible, storing generated or harnessed energy is very important due to two significant reasons: renewable energy sources are generally have an intermittent characteristic and system capacities can't response for instant energy demand increases.

Energy storage is a topic which has been investigated intensively for aforementioned systems where grid support is out of the question. Batteries that include chemical reactions to store and release electricity are the ones that come to mind in the first place. Storing heat by phase changing materials such as salts, thermo-chemical heat storage materials such as salt hydrates, capacitors and hydrogen as an energy vector can be listed as alternatives. Kleiner et al. (2017) mentioned about salt hydrates of $\mathrm{MgSO}_{4}, \mathrm{ZnSO}_{4}$ and $\mathrm{SrCl}_{2}$ as promising thermo-chemical heat storage materials for later use of energy generation. They investigated the thermal conductivity of these materials in order to provide information for the optimization of this storage method. Another important point of this type of thermal storage is emphasized by the authors that these materials store thermal energy relatively much more time comparing to salt and/or water heat storage tanks. In the proposed system schematics of Amusat et al. (2017), three different energy storage system were mentioned; i.e., Pumped Hydro Energy Storage System, Advanced Adiabatic Compressed Air Energy Storage system and Molten Salt Tank system. They investigated a sophisticated hybrid renewable energy generation system including these energy storage systems from the aspect of reliability of the field application. Allison (2017) studied the multiobjective control of a system containing solar energy electricity conversion system with the aid of an electrical battery unit. The author stresses the importance of complex control systems and the need of energy storage systems, in particular, batteries. Steam, water and oil are all used in a single integrated combined power system as a heat storage sub system in the paper of Hu et al. (2017). Chong et al. (2016) tried to attract attention to another important part of energy storing efforts for renewable energy systems. The life span of these aforementioned energy storage systems were reported to be short by the authors due to the irregular output of the renewable energy systems. They proposed hybrid energy storage systems and decision matrixes. An interesting report was provided by Nojavan et al. (2017) about utilization of electrolyzer, hydrogen and fuel cell as a renewable energy storage system. They evaluated variables such as intermittent characteristics of renewable energy sources, market prices, demand change and etc.

Hydrogen is an important material not only for energy systems but also for any industrial applications as a raw material. Hydrogen should not be regarded as an energy source because it cannot be found freely in the nature. Instead, hydrogen exists as part of other compounds. Generated energy can be used to break these bonds and released hydrogen that has a high reaction potential can be stored for later use. It can be used by combustion or by fuel cells. Another type of utilization is the bonding with carbon atoms. By this way, methane and methanol can be synthesis and carbon dioxide also can be captured in order to lower its impact on the environment. When hydrogen containing molecules are synthesized, the densities increase and therefore required pumping work decreases. It leads to desired flexibility for energy storage and transportation. The important point here is the strength of the bonds between atoms of the synthesized molecules should be relatively weaker so that oxygen can react with hydrogen when sufficient activation energy is presented. So hydrogen is generally regarded as an energy vector or in other words energy cycle fluid. Therefore it is an important candidate for energy transportation with relatively lower energy losses. Energy generated and desired to be transported in North Africa is a good example for this task. In this sense, hydrogen is particularly important than local energy storage systems such as water potential energy storage systems. Hydrogen bond to carbon can be 
stored easily compared to pure hydrogen. This is due to the size of hydrogen atoms. Pure hydrogen can escape almost any storage. The only reason of pure hydrogen storage systems is their structure that slows down the movement of hydrogen atoms. Whether hydrogen is stored in its pure form or bond to carbon or other matter, there are a lot of researches going on about the topic. Four main methods for storing hydrogen can be mentioned here. The first one is the natural storing in caves and similar voids in the ground. Since diffusion of hydrogen in the ground is relatively slow and there is no hazardous effect, this is a favorable solution when short term storage is needed to damp excess or insufficient production. There is a remarkable study of Bai et al. (2014) about the underground storage possibilities of hydrogen. Authors summarized the opportunities and the works going on all around the world and they also give local information. They exemplify some underground depots such as depleted reservoirs, aquifers, salt caverns and excavated caverns. The second method is the pressurized depots or in other words pressurizing. This solution is for smaller systems such as vehicles or small electrolysis units. Ali et al. (2016) utilized Matlab Simulink software similar to the present work and considered the pressurized hydrogen storage in their model. They also made an examination for the possible leakages and concluded that their model is proper for relatively lower pressures. Fan et al. (2017) also considered a pressurized hydrogen tank for their hybrid renewable energy system. They operated this tank for four different modes. Their whole system exhibits similarities with the current work. There are known issues about the compressed hydrogen storage, i.e. metal fatigue due to load cycles of the storage, embrittlement of storage material due to the existence of hydrogen etc. So Guo et al. (2016) focused on hydrogen gas cycling tests based on multi-stage storage and self pressurizing method. Also thin films from multi-elemental sources for hydrogen storage applications are investigated and reported (Akyildiz and Öztürk, 2013). The third one is the metal hydride hydrogen storages. Hydrogen is contained in the crystal lattice structures in a stable manner in this solution. One of the mines used for metal hydrides is the boron mineral and it is abundant in Turkey. However metal hydride hydrogen storage is still expensive for certain applications. The topic is particularly attracting attention because of the quasiinfinite possibilities in material research. A solid state hydrogen storage tank based on complex hydrides and to fully integrate it with a High Temperature Proton Exchange Membrane fuel cell stack objective was asserted by Baricco et al. (2017). A mixed lithium amide/magnesium hydride system was used as the main storage material for the tank by the authors and it was equipped with a high temperature PEM fuel cell. It is said that the storage system cooperates with the high temperatures and can release hydrogen with relatively low temperatures, that is $170{ }^{\circ} \mathrm{C}$. An extensive literature review was conducted by $\mathrm{Yu} e t$ al. (2017) and it is very useful for this content. They look for the recent advances and remaining challenges for the hydrogen storage and consider the nano-materials in respect of the improvement. Reader can find information about metal hydrides for the hydrogen storage as well as molecular hydrogen storage and chemical hydrogen storage. Another comprehensive review was reported by Kumar et al. (2017) about vanadium based hydrogen storage material. They suggested that vanadium is a good alternative for the metal hydride hydrogen storage materials. Other superior properties can be given as high hydrogen solubility and diffusivity in the material at nominal temperature and pressure conditions. The last one is the chemical fuel synthesis though these produced fuels cause exhaust emissions similar to their fossil fuel counterparts. An example is to convert hydrogen with carbon dioxide to methanol and higher alcohols (Nieskens et al., 2011). A fixed bed reactor was used for the conversion reaction and 3 times the $\mathrm{H}_{2}$ is mentioned to be needed for one unit of $\mathrm{CO}_{2}$ to reach significant levels of conversion. 470-530 K and 5-19 MPa are reported to be the convenient intervals for the conversion of hydrogen and carbon dioxide to methanol (Ostrovskii, 2002). The author focused on the problems of heterogeneous catalyst situation and investigated the mechanisms for $\mathrm{Cu}-\mathrm{Zn}$ containing catalyst. As a conclusion, storing hydrogen in short term relatively cheap solutions and using it with a fuel cell seems logical. Another chemical hydrogen storage system is proposed by Zhong et al. (2017). Authors underline that the hydrolysis of $\mathrm{NaBH}_{4}$ offers significant advantages for hydrogen storage in fuel cells, whereby suffers from the irreversibility. Hence they focused on a simple and low cost method for $\mathrm{NaBH}_{4}$ regeneration from its hydrolysis byproduct. In the absence of an additional hydrogen source, 
they utilized ball milling at ambient conditions and by his way they obtained the reaction of magnesium silicate and dehydrate sodium metaborate.

Hydrogen can be used as a fuel in internal and external combustion engines. An important point here is the hardening of the combustion chamber walls due to the presence of the hydrogen and therefore occurring early fatigue in long term operation. Using a fuel cell for generating electricity for hydrogen as a fuel seems to be the most efficient way to use hydrogen as an energy vector. The only drawback of this option is the initial cost of the systems. Prices are decreasing lately and efficiencies of the systems are going up. So fuel cell option becomes more favorable with passing years. Pure hydrogen as well as methanol and methane can be used directly in fuel cells. Some informative literature examples are as follows. Kivrak et al. (2013) investigated some elements for their direct ethanol fuel cell catalyst usage. They also included structures at nano scale in their work. A novel fuel cell design is proposed by Esquivel et al. (2017) which include single use papers in order to aid point of care diagnostic applications. Their proposed design utilizes capillary action for the fluid movement and an exothermic reaction which releases hydrogen as a byproduct. This design actually works as a hydrogen sensor and the amount of hydrogen gives information about the liquid dropped on to the design. "More electric aircraft" term in the recent years leaded Guida and Minutillo (2017) to study the potential of a PEM fuel cell in aircrafts. The authors analyzed the feasibility, from the specific energy point of view, in using a PEM fuel cell power system as APU unit in a more electrical aircraft with respect to a battery system installation. Since fuel cells uses hydrogen as a fuel and they have relatively complex structures, feeding hydrogen is an issue and Jia et al. (2017) focused on this subject. They stressed that existence of hydrogen starvation for a fuel cell can detrimental effects on the unit. They investigated mitigation strategies for the hydrogen starvation. Fuel cell combined heat and power plants attract attention of the scientists due to the relatively higher temperatures experienced during electricity generation by fuel cells. The heat released from the fuel cell can be used for the benefit of facilities and this increases total efficiency of the system. Mamaghani et al. (2017) constituted a model for prediction of the HT-PEM unit and try to assess adaptive long term optimization. Mohamed and Kamil (2016) investigated the preheating of hydrogen by using a waste heat recovery system as an energy source and evaluate the power output improvement for an open cathode PEM fuel cell system. They suggest a potential for hydrogen preheating by using the waste heat from the fuel cell stack though only 3-6\% of the waste heat can be used due to the small amount of hydrogen flowing in the system.

Fuel cells and electrolyzer units operate on the same basic principle. Fuel cells can be thought inversely working electrolyzer or vice versa. $20 \%$ of the world hydrogen generation comes from the electrolysis method. The purest hydrogen can be acquired by electrolysis. Generating hydrogen by electrolysis is not a good candidate for constituting energy vector of the future since its electricity cost is higher than the energy obtained by using hydrogen in various energy conversion methods. There are emission constraints for the hydrogen generation from coal or natural gas. Of course there are novel techniques too; for instance Lashgari et al. (2017) proposed a highly efficient p-n junction nanocomposite solar-energy-material for direct conversion of water molecules to hydrogen. They investigated the presence of the carbon nanotubes for their solar-energy material and found that the photo catalyst acts twice efficient. Another example is the report of Izgi et al. (2016) in which the effect of $\mathrm{NaOH}$ on hydrogen production from $\mathrm{NaBH}_{4}$. Since Sodium hydroxide concentration in hydrogen production from sodium boron hydride is immensely important to stabilize the reaction, and boron is an important candidate for storing hydrogen, the study is important in this aspect. Electrolysis can be thought as an alternative for storing energy when grid support is out of option and electricity is generated by renewable and there is an excess of supply. Fallisch et al. (2017) proposes a PEM water electrolysis cell design as a candidate for highly efficient solar hydrogen generator which is needed in countries having abundant of renewable energy. Their work also contains content such as "Hydrogen Concentration", "on cell PEMs", "multi-junction Solar Cells" and etc. On the other hand, higher rates of hydrogen production can be achieved by application of microbial electrolysis cells as mentioned in the report of Guo et al. (2017). They proposed a low resistance reactor design and reported a high hydrogen purity as 
high as $>98 \%$. They also mentioned that their reactor can operate in a stable manner up to three weeks. Anion exchange membrane electrolysis is mentioned by Vincent et al. (2017). They underlined the benefit of using anion exchange membrane by using with non noble metals in the catalyst layer will lead to lower initial costs. Their best electrolysis performance is reported as $500 \mathrm{~mA} \mathrm{~cm}{ }^{-2}$ for $1.95 \mathrm{~V}$ at $60{ }^{\circ} \mathrm{C}$ with $1 \% \mathrm{~K}_{2} \mathrm{CO}_{3}$ electrolyte. Zhang et al. (2017) reported a novel electrode for solid oxide electrolysis cell and found that $\mathrm{H}_{2} \mathrm{O} / \mathrm{H}_{2}$ adsorption desorption or surface diffusion process is the main rate-limiting step for steam electrolysis reaction.

There are also modeling studies similar to this work. A study considering a solar hydrogen system was reported by Boudries (2013) in Algeria. The results indicate that concentrated solar power is more convenient for the solar hydrogen systems. Ngoh et al. (2014) designed and simulated a high temperature solar-hydrogen hybrid system in order to generate hydrogen. Exergy analysis and source utilization are also reported.

This study, which is a compact summary and reorganized form of a MSc thesis of Zendehdel (2016), comprises mathematical model of three systems and combines these models in to one single system model. These systems are; firstly photovoltaic electricity production system; secondly hydrogen production system and thirdly fuel cell system. The mathematical formulation of each system and the main model for the whole system are provided. System parameters are explained and system behavior as produced hydrogen and system efficiencies are illustrated. Both system model and the potential of such systems for considered case site can be regarded as the valuable outcomes of this study.

The main objective of this research is to evaluate the potential of a combined system comprising a PV system, an electrolyzer system and a fuel cell system for small scale energy consumers away from the electricity grid such as rural areas in terms of continuity and avoiding intermittent characteristics of the renewable energies.

The novel contribution to the specific literature can be stated as the local real world data used as input for the present system to be simulated. By this way, domestic potential can be assessed. A detailed literature survey alongside of the directions to the future work possibilities are also other favorable contributions to be listed. The simulation presented here can be used in order to avoid costly trial and error approaches or in other words reduce the possibilities.

\section{MATERIAL AND METHOD}

A schematic drawing of the general system is provided in Figure 1. As it can be seen from the figure, the main energy source is the sun. The energy transported through the sun rays is harnessed via PV and thermal solar collector panels in electricity and thermal heat forms. Of course some of the radiation is reflected and some of the radiation passes through the panels. Absorbed energy is converted with conversion efficiency. The heated water is fed to the electrolyzer with a manner to satisfy the thermal energy need of the electrolyzer. For the generated electricity, things are relatively complicated. A power regulator was utilized in order to regulate the electrical power. A portion of the electricity is sent to the batteries through the charge control unit and rest is sent to the electrolyzer in the supervision of the ECU. Again batteries supply the electrolyzer unit. Generated hydrogen first stored in a pressurized tank and then sent to the Proton Exchange Membrane (PEM) fuel cell. The oxygen $\left(\mathrm{O}_{2}\right)$ obtained via electrolyses are released to the atmosphere. Oxygen is supplied to the PEM by using atmospheric air. The whole system is operated by the ECU and the simulation is operated by the Matlab Simulink software.

All data about the environment and the solar radiation of Konya City were gathered from Meteorology Regional Directorate of Turkey and fed to the system mathematical model for the simulation. Block diagrams were utilized in Matlab Simulink software in order to ease the simulation process. Since numerous system components are exist, sub-systems were created and applied similarly. In the following part, diagrams of the simulation process and related equations of the mathematical model are provided respectively. 
Figure 2 presents the main flow chart. Other diagrams for the sub systems refer to this main flow chart. The input parameters of the simulation system are given in Table 1. Respectfully, Figure 3 exhibits the block diagram of the energy harnessing part of the main system and related equations follow it.

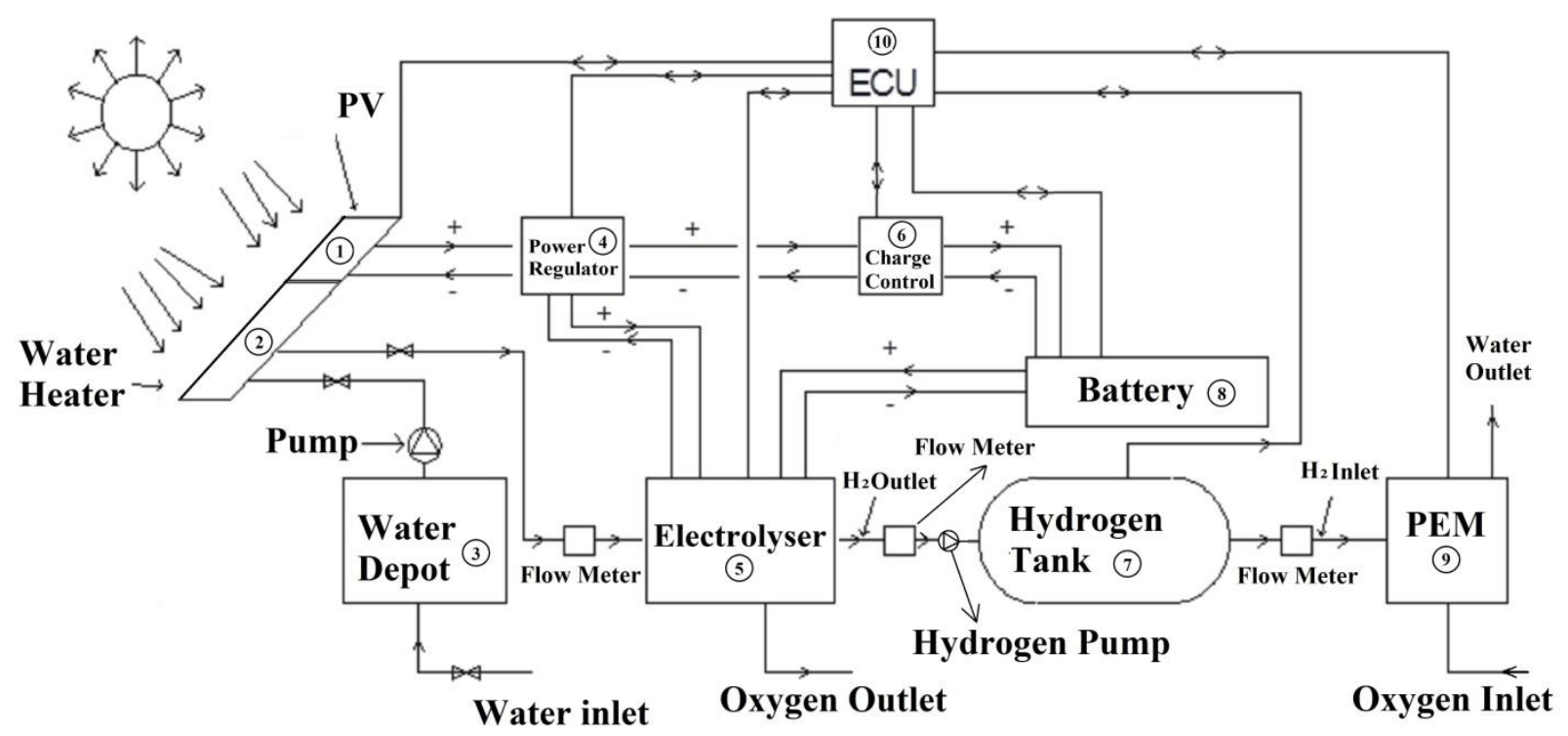

Figure 1. Schematic drawing of the simulated system

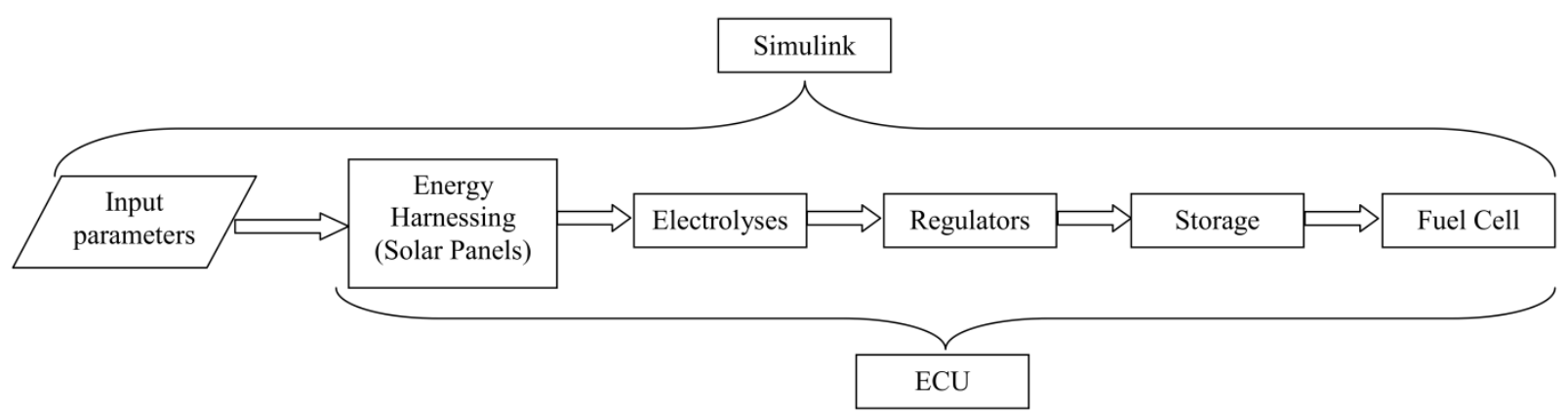

Figure 2. Main flow chart of the simulation system

Table 1. Input parameters of the system

\begin{tabular}{|cc|ccc|}
\hline $\begin{array}{c}\text { Solar Radiation of } \\
\text { Konya }\end{array}$ & $\begin{array}{c}\text { Ambient Air } \\
\text { Temperature }\end{array}$ & $\begin{array}{c}\text { Electrolyzer Stack } \\
\text { Temperature (K) }\end{array}$ & $\begin{array}{c}\text { Electrolyzer Stack } \\
\text { Pressure (kPa) }\end{array}$ & $\begin{array}{c}\text { Electrical } \\
\text { Conversion } \\
\text { Efficiency of the } \\
\text { PV System (\%) }\end{array}$ \\
\hline Monthly average values for 12 months \\
(January to December) & 353 & 100 & 11.5 \\
& 393 & 200 & 13.5 \\
& 473 & 400 & 17 \\
\hline
\end{tabular}




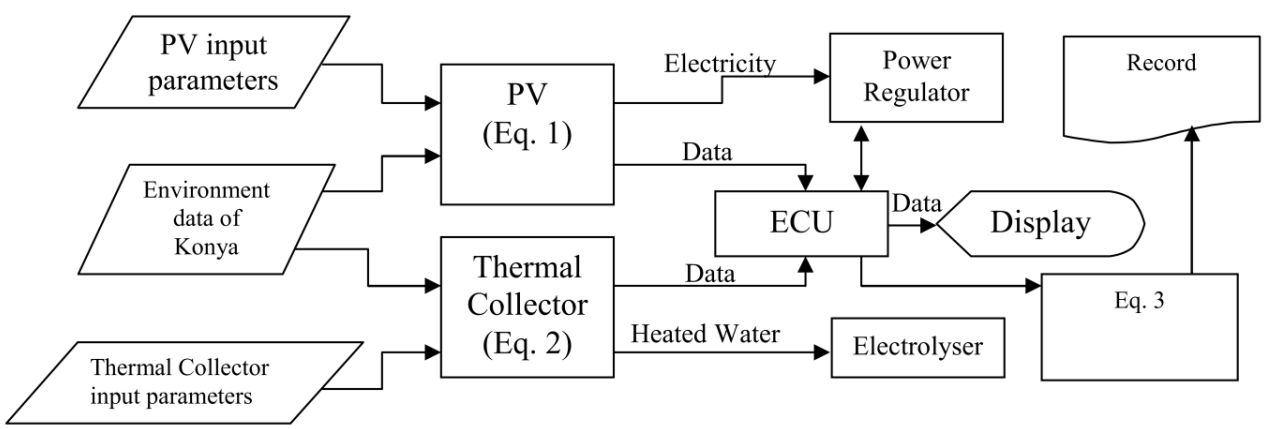

Figure 3. Energy harnessing sub system

The generated energy in the form of electricity in the PV can be expressed as following (Padin et al., 2000):

$$
E_{P V}=\eta_{P V} A_{P V} q C
$$

Here $E_{P V}$ is the generated electricity amount in Watt, $\eta_{P V}$ is electricity efficiency of the solar panels, $A_{P V}$ is the area of the PV panels, $q$ is the heat flux in radiation form of solar energy per unit area. $C$ is the correction factor. Generated thermal energy is as following (Padin et al., 2000);

$$
E_{S C}=\eta_{S C} A_{S C} q C
$$

Again $E_{S C}$ is the thermal energy transferred to the water in Watt, $\eta_{S C}$ is thermal efficiency of the thermal solar collectors, $A_{S C}$ is the area of the thermal solar collectors. Total solar energy harnessed by the collectors is:

$$
E_{t o t}=q C\left(\eta_{P V} A_{P V}+\eta_{S C} A_{S C}\right)
$$

The second sub system is the electrolyzer sub system. Figure 4 presents this sub system and following are the related equations. Electricity is provided to the electrolyzer in two ways. The whole electricity generated from the PV system is directed to the power regulator. A portion of this energy is sent to the electrolyzer while the remaining part is sent to batteries in order to provide electricity to the electrolyzer when the generated electricity from PV system is insufficient.

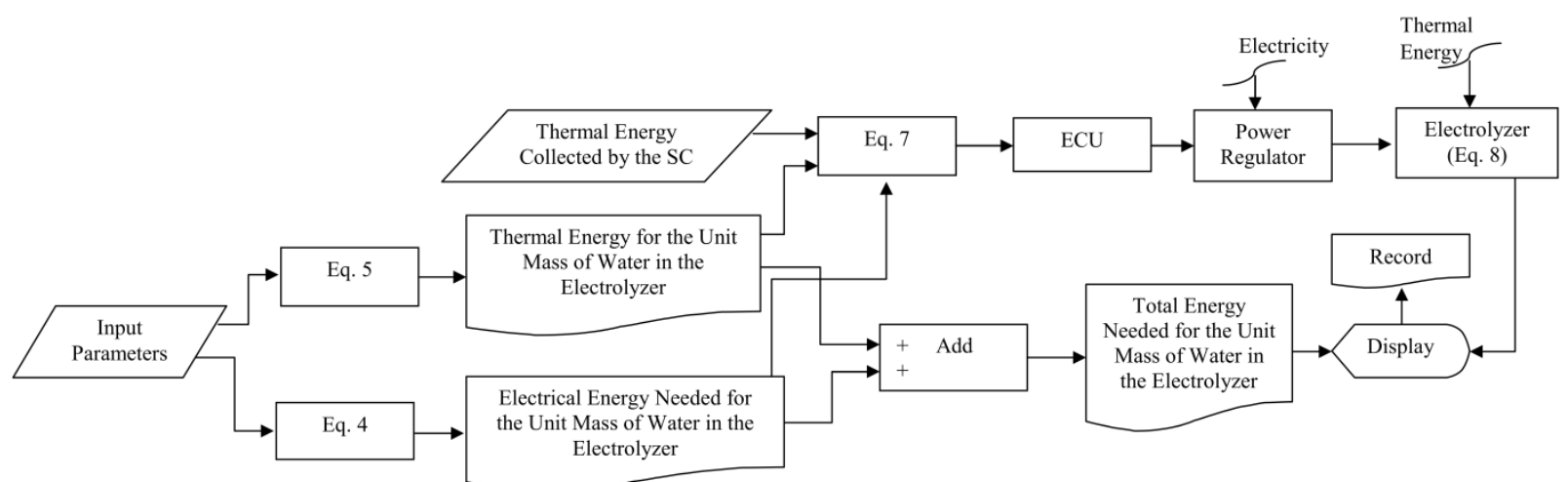

Figure 4. Electrolyzer sub system 
The electrical energy electrolyzer uses for the unit mass of water can be expressed as following (Rzayeva et al., 2001):

$$
e_{e}=U / R\left(6.5 \times 10^{-5} T \ln (P)\right)
$$

Here $U$ is the voltage needed for the electrolyses and it is between $U=1.233-1.48$ in Volts. $R$ is the electrolyzer resistance in ohm $(\Omega), T$ stands for Temperature of the electrolyzer in Kelvin, $P$ stands for the pressure of the electrolyzer in $\mathrm{kPa}$. Thermal energy entering to the electrolyzer via solar collector for unit mass of water is (Padin et al., 2000);

$$
e_{t h}=T \Delta s / t
$$

$\Delta s$ is the entropy difference for the electrolysis of the unit mass of water which is $116 \mathrm{~J} / \mathrm{kgK} . t$ stands for time in seconds. Total energy consumption of the electrolyzer is:

$$
e_{t o t}=e_{e}+e_{t h}
$$

The electrical energy needed by the electrolyzer is calculated by:

$$
E_{\text {elec }}=\left(\frac{E_{S C}}{e_{t h}}\right) e_{e}
$$

The hydrogen generated by the electrolyzer is:

$$
\dot{m}_{\mathrm{H}_{2} \mathrm{O}}=\frac{E_{S C}}{9 e_{t h}}
$$

The third sub system is the power regulator which regulates the amount of electricity sent to batteries and the electrolyzer. Figure 5 is arranged for the power regulator.

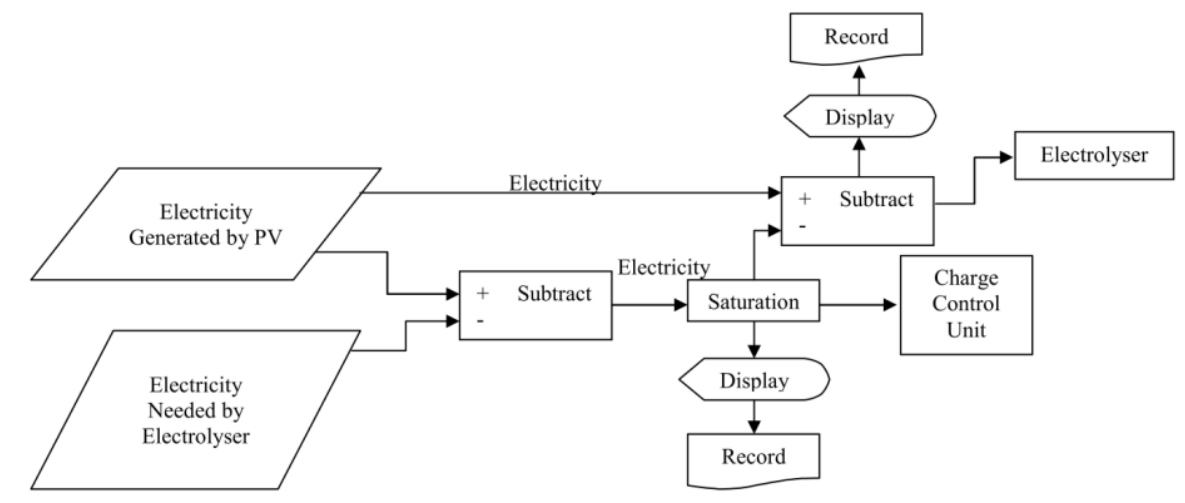

Figure 5. Power regulator sub system

The whole electricity generated from the PV system is directed to the power regulator. A portion of this energy is sent to the electrolyzer while the remaining part is sent to batteries in order to provide electricity to the electrolyzer when the generated electricity from PV system is insufficient. The extra 
energy remained from the PV after the need of the electrolyzer is subtracted can be calculated by (9) and the stored electrical energy in the batteries can be calculated by the following equation.

$$
\begin{gathered}
E_{e x}=E_{P V}-E_{e l e c} \\
E_{b a t}=\eta_{c h} \eta_{b a t} E_{e x}
\end{gathered}
$$

$\eta_{c h}$ and $\eta_{b a t}$ are efficiencies of charge control unit and the battery unit respectively and 0.9 was assumed for both of them. The cell voltage of the PEM fuel cell can be found by (Ziogou et al., 2011):

$$
V_{\text {cell }}=E_{\text {Nernst }}-V_{\text {act }}-V_{\text {ohm }}-V_{\text {conc }}
$$

$E_{\text {Nernst }}$ is the voltage without load in $\mathrm{V}, V_{\text {act }}$ is the activation voltage drop in $\mathrm{V}, V_{\text {ohm }}$ is the ohmic voltage in $\mathrm{V}$ and $V_{\text {conc }}$ is the excess voltage in $\mathrm{V}$ here. The electricity generated by the PEM is:

$$
P=I \times V_{\text {cell }}
$$

The Nernst equation is provided below (Larminie et al., 2003):

$$
E=E_{0}-0.85 \times 10^{-3}(T-298.15)+\frac{R T}{2 F} \ln \left(\frac{p_{\mathrm{H}_{2}} p_{\mathrm{O}_{2}}{ }^{0.5}}{p_{\mathrm{H}_{2} \mathrm{O}} P^{0.5}}\right)
$$

Here $E_{0}$ is the reference voltage in $\mathrm{V}, R$ is the universal gas constant in $\mathrm{J} / \mathrm{molK}, T$ stands for temperature in $\mathrm{K}, F$ is the Faraday constant in ${ }^{\circ} \mathrm{C} / \mathrm{mol}$ and $p$ stands for partial pressures in atm. The activation voltage can be calculated by the Tafel equation (Amphlett et al., 1995).

$$
V_{a c t}=-E_{a c t}=-\left[\begin{array}{l}
-0.9514+0.00312 T \\
-0.00018 T T(\ln I) \\
+7.4 \times 10^{-5} T\left(\ln C O_{2}\right)
\end{array}\right]
$$

$\mathrm{CO}_{2}$ here can be calculated from the following empirical formula (Amphlett et al., 1995).

$$
C \mathrm{O}_{2}=\frac{p_{\mathrm{O}_{2}}}{5.08 \times 10^{6} \exp (-498 / T)}
$$

The effect of double layer capacitance of the inter layer of electrode and electrolyte can be defines as (Larminie et al., 2003):

$$
\frac{d V_{a c t}}{d t}=\frac{I}{C_{d l}}-\frac{V_{a c t}}{R_{a c t} C_{d l}}
$$


$C_{d l}$ here is the double layer capacitance and $R_{a c t}$ is the activation resistance in $\mathrm{k} \Omega . \mathrm{cm}^{2}$ which can be calculated by dividing $V_{a c t}$ to the cell current. The voltage drop for the average current is nearly linear and ohmic in its natural state (Ceraolo et al., 2003).

$$
V_{\text {ohm }}=I R_{\text {mem }}
$$

$R_{\text {mem }}$ is the resistance of the membrane. It can be calculated by (18) (Ural, 2007).

$$
R_{m e m}=\frac{t_{m}}{\sigma}
$$

$t_{m}$ is the thickness of the membrane in $\mathrm{cm}$ and $\sigma$ is the conductivity of the membrane. In order to define concentration of the proton $\left(\mathrm{C}_{\mathrm{H}}\right)$, the empirical formula (19) is given and $\sigma$ can be estimated by using (20) (Marr and Li, 1997).

$$
\begin{aligned}
& \frac{d C_{H^{+}}}{d t}+\frac{C_{H^{+}}}{\tau_{H^{+}}}=\frac{1+\alpha_{H}+I^{3}}{\tau_{H^{+}}} \\
& \sigma=\frac{F^{3}}{R T} D_{H^{+}} C_{H^{+}}
\end{aligned}
$$

Cell potential decreases rapidly due to mass transfer limitations at higher electrical currents. This non linear behavior is called excess voltage (Kim et al., 1995) and can be calculated by using the following empirical formula:

$$
\begin{aligned}
& V_{\text {conc }}=a \times e^{(b I)} \\
& a=1.1 \times 10^{-4}-1.2 \times 10^{-6}(T-273) \\
& b=8 \times 10^{-3}
\end{aligned}
$$

Using conservation law, governing equations and reactant flow model together while assuming ideal gas law for the dynamic analyses, (22) can be constituted (Gemmen, 2001).

$$
\frac{V}{R T} \frac{d P_{g}}{d t}=m_{\text {in }}-m_{\text {out }} \pm \frac{I}{n F}
$$

$V$ stands for volume here in $\mathrm{m}^{3}$ and $m$ stands for flow rate in mol. $n$ is the number of electrons for each molecule. Equation (22) can be modified for anode and cathode as stated in (23) and (24) respectively (Gemmen and Farmouri, 2002).

$$
\begin{aligned}
& \frac{V_{a}}{R T} \frac{d P_{\mathrm{H}_{2}}}{d t}=m_{\mathrm{H}_{2} \text { in }}-m_{\mathrm{H}_{2} \text { out }}-\frac{I}{2 F} \\
& m_{\mathrm{H}_{2} \text { out }}=k_{a}\left(P_{\mathrm{H}_{2}}-P_{\text {amb }}\right) \\
& m_{\mathrm{H}_{2} \text { in }}=F R_{\mathrm{H}_{2}} P_{\mathrm{H}_{2}} C_{\mathrm{H}_{2}}
\end{aligned}
$$




$$
\begin{aligned}
& \frac{V_{c}}{R T} \frac{d_{O_{2}}}{d t}=m_{O_{2} \text { in }}-m_{O_{2} \text { out }}-\frac{I}{4 F} \\
& m_{O_{2} \text { out }}=k_{c}\left(P_{O_{2}}-P_{\text {amb }}\right) \\
& m_{O_{2} \text { in }}=F R_{O_{2}} P C_{O_{2}} C F_{O_{2}}
\end{aligned}
$$

\section{RESULT AND DISCUSSION}

Konya is located in northern hemisphere of the world and it is above tropic of cancer. The latitudes are $36041^{\prime}$ and $39016^{\prime}$ while longitudes are $31014^{\prime}$ and 34026'. Due to its geographical location, it receives favorable amount of solar radiation in respect of energy. Figure 6 gives a good idea of the PV electricity generation potential of the site and the region. Since real world data of the insolation periods and solar radiation were used for the calculations, one can see that there is an electricity generation potential for the whole year and this potential reaches to a maximum during summer months which are June, July and August. Of course the conversion efficiency of the PV system plays a crucial role for the system power output and determines the basic payback period of the system. This is particularly important for the investors. The efficiencies in Figure 6 cover a practical range and these values are long achieved by the manufacturers not only at cell level but also for the laminated panels.

For the first part of the results section, three PV efficiencies were taken into consideration. These values are 11\%, 13.5\% and 17\%. It can be seen from Figure 6 that the maximum power harnessed from the PV setup can reach to $1800 \mathrm{~W}$ at peak solar insolation months while the minimum amount is about $300 \mathrm{~W}$.

Four different electrolyzer temperatures were considered and these are $353 \mathrm{~K}, 373 \mathrm{~K}, 393 \mathrm{~K}$ and 473 $\mathrm{K}$. This is particularly important since the design and material selection of such system are done accordingly. Higher temperatures were not considered because this temperature interval is appropriate for small scale systems and easy to handle for operation. Additionally three different electrolyzer pressures were used and these values are $100 \mathrm{kPa}, 200 \mathrm{kPa}$ and $400 \mathrm{kPa}$. Simulations were run for these aforementioned parameters and values. Data can be illustrated by three dimensional graphics however reading those graphics is difficult so two dimensional graphics are preferred instead. These graphics are presented for constant electrolyzer temperatures and constant electrolyzer pressures. Results indicate that thermal energy input reduces electricity need of the electrolyzer for the same amount of generated hydrogen and temperature of the electrolyzer increases the hydrogen generated.

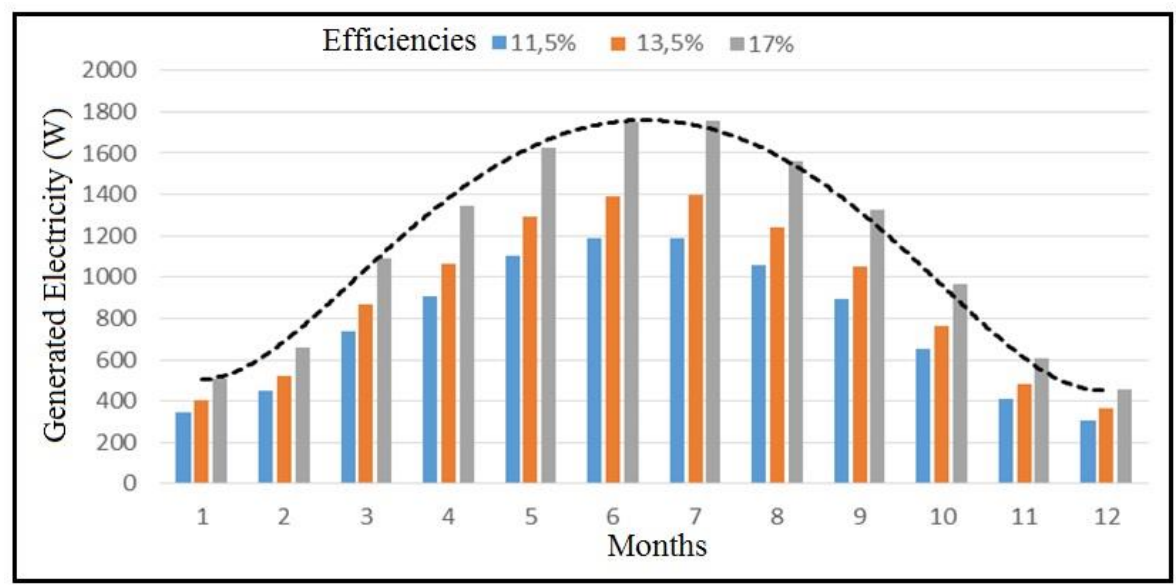

Figure 6. Electrical energy generation for different PV efficiencies versus monthly average insolation periods of KONYA

The energy required for the electrolysis is equal to the change of enthalpy (Padin et al., 2000): 


$$
\Delta H=\Delta G+\Delta Q=68.3 \mathrm{kcal} / \mathrm{mol}
$$

Here $\Delta G$ is Gibbs free energy and $\Delta Q$ is the change of thermal energy per mol of water. While equations (4), (5), (7) and (8) in mind, equation (25) is very useful for the evaluation of the following figures. Since total energy is constant for an amount of water to be spliced by electrolysis, the thermal energy input reduces the electrical energy input for the same amount of generated hydrogen. In other words, more hydrogen can be generated for the same amount of electricity generated from PV panels by means of increasing thermal energy input. Because of there is storage opportunity for the electricity and thermal energy obtained from the solar collectors should be used instantly, particularly for the systems away from the grid support and there is no need for the excess thermal energy, this option seems logical. A portion of electricity can be stored for the periods with no sun light. By this way, constant hydrogen generation can be attained during day and night. Hence this scenario can be observed and examined by figures 7, 8, 9 and 10. These figures should be evaluated together. A three dimensional figure can lower the number of figures however this time reading data becomes difficult.

The effect of electrolyzer temperature and pressure can be observed in used electricity in the electrolyzer and the difference in generated hydrogen considering the equation (4) and (5). Temperature and pressure affect the unit energies by affecting Gibbs free energy and the entropy difference for the thermal energy input. These effects are relatively small though, because the main determining mechanism is the energy input to the system determining the share of the electricity and the thermal energy in the electrolysis process.

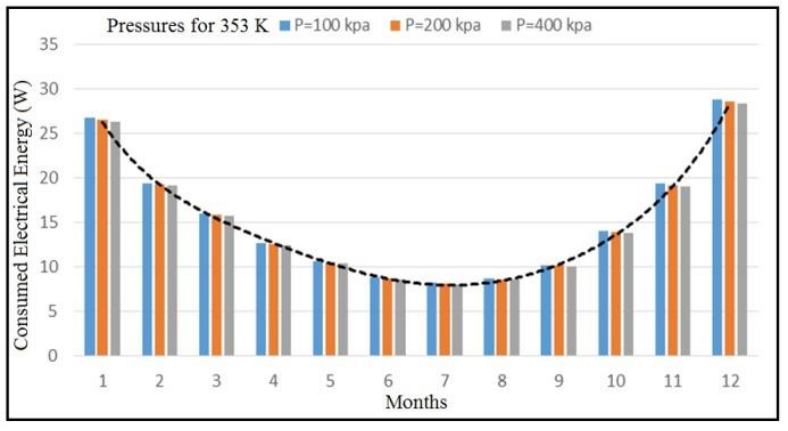

a

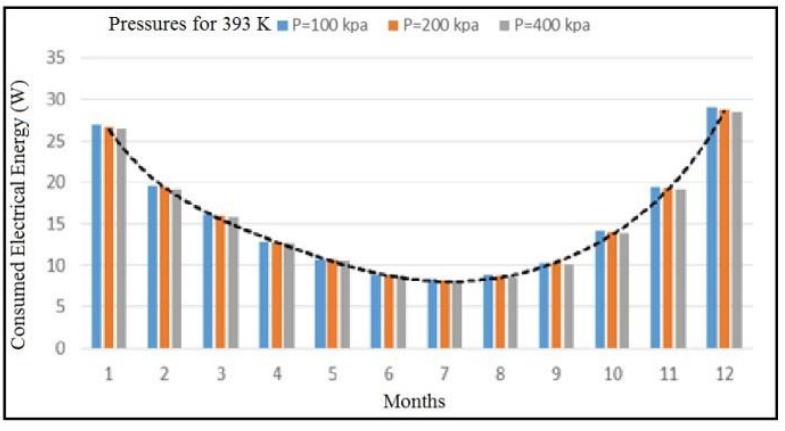

C

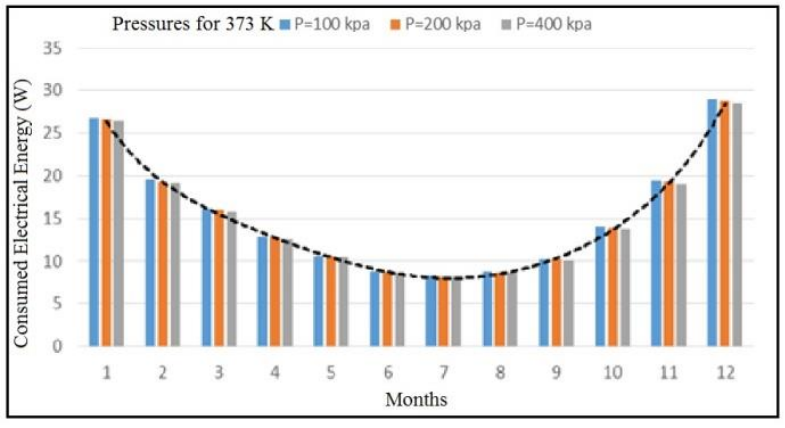

$\mathrm{b}$

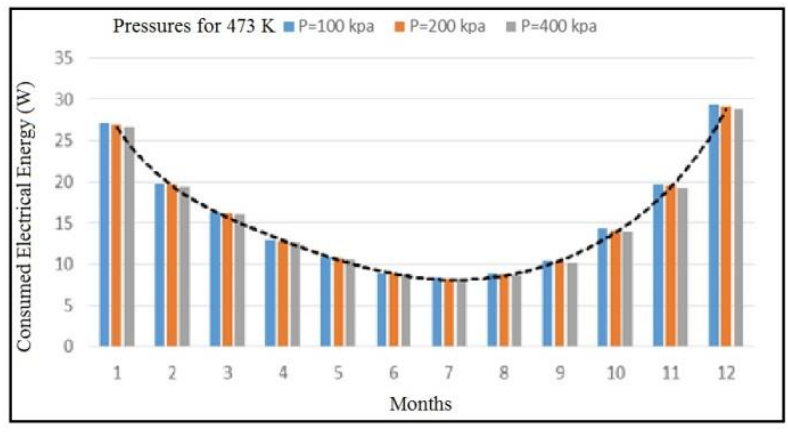

d

Figure 7. Electrolyzer electricity consumption for fixed temperatures

The share of the electricity in the electrolysis process goes down with the increase in the thermal energy input to the electrolyzer. PVs with integrated heat exchangers, i.e. PVTs, are of interest due to this fact. Thermal heat collectors cool down the PVs in order to protect their efficiency levels while generates heat energy for various aims, reducing electricity need of the electrolyzer for the generated hydrogen amount this time. The least or minimum values can be seen in summer months because of the 
increasing thermal energy which is directly supplied to the electrolyzer without any thermal store or waste heat. The electricity power changes between 8 Watts and 29 Watts in the season.

The change in electrolyzer pressure reduces the need of electricity in a slight manner while the temperature of the electrolyzer increases electricity need slightly due to the change in the unit electrical energy need for the Gibbs free energy.

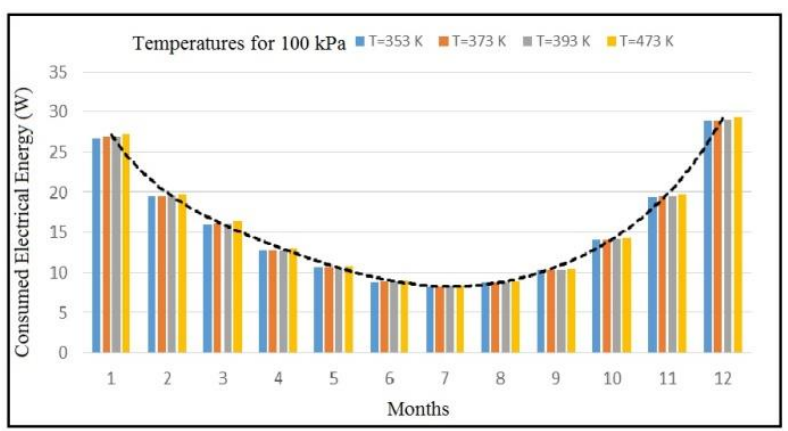

a

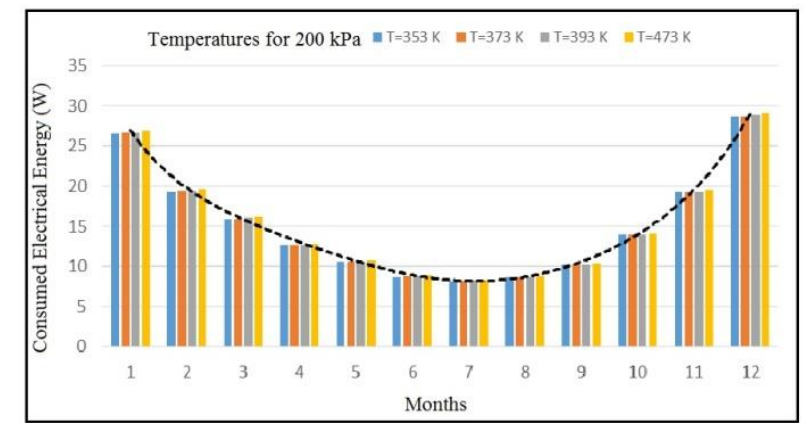

$\mathrm{b}$

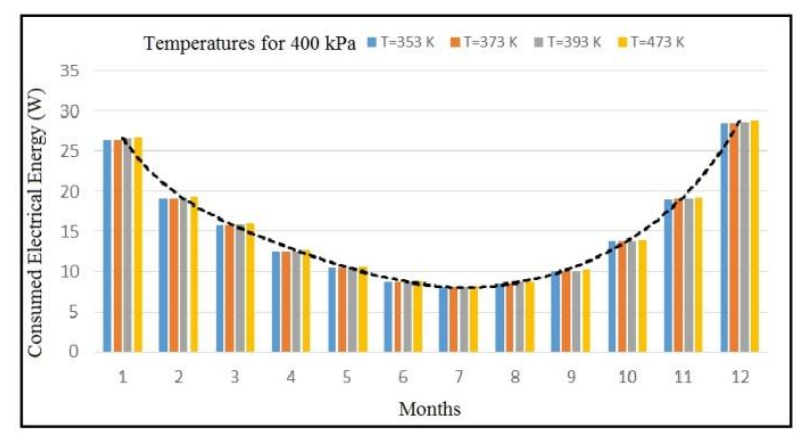

C

Figure 8. Electrolyzer electricity consumption for fixed pressures

On the other hand temperature directly affects the generated hydrogen throughout the year. While hydrogen amounts between $120 \mathrm{~g} / \mathrm{m}$ and $132 \mathrm{~g} / \mathrm{m}$ can be obtained by the proposed system, the contribution of the temperature level is nearly $10 \%$ to the production. This is due to the change of entropy levels with temperature. The thermal energy enters to the system is spent with lesser unit energy cost when the temperature is relatively high. These data clearly show that higher temperatures yield higher hydrogen generation rates. This evaluation is also made by several scientists whose reports indicates information about this phenomenon and one example can be find in Padin et al. (2000). As an instance for the hydrogen production, $130.94 \mathrm{~g} / \mathrm{h}$ is generated in July for the $473 \mathrm{~K}$ and $100 \mathrm{kPa}$. For the $393 \mathrm{~K}$, the hydrogen production drops to approximately $127.5 \mathrm{~g} / \mathrm{h}$ and the remaining two values are $126.5 \mathrm{~g} / \mathrm{h}$ and $125.5 \mathrm{~g} / \mathrm{h}$ for $373 \mathrm{~K}$ and $353 \mathrm{~K}$ respectively. In the reference work of Ngoh et al. (2014) similar to this work, the theoretical production rate of hydrogen per second and per day recorded from simulation of interconnected system based on optimum scenario are respectively $0.064 \mathrm{~kg} / \mathrm{s}$ and 1843.2 $\mathrm{kg} /$ day. The fresh water consumption rate in that study is around $0.7168 \mathrm{~kg} / \mathrm{s}$. So the fresh water required per day is stated as $30.967 \mathrm{~m}^{3}$. Boudries (2013) on the other hand reported the mean value over the country of the hydrogen production potential per unit cell area is about $0.14 \mathrm{~kg} \mathrm{H}^{2} / \mathrm{m}^{2}$ day for the least favorable month; while this value is about $0.19 \mathrm{~kg} \mathrm{H} / \mathrm{m}^{2}$ day for the most favorable month. Parabolic trough reflector stated as an alternative in that study, yielded results as about $0.10 \mathrm{~kg} \mathrm{H}^{2} / \mathrm{m}^{2}$ day for the least favorable month and about $0.17 \mathrm{~kg} \mathrm{H}^{2} / \mathrm{m}^{2}$ day for the most favorable month. Of course there are still differences in parameters and environmental inputs with these studies and present work. However, they still indicate the potential of the hydrogen electrolysis and the possibility to use hydrogen as an energy vector. 


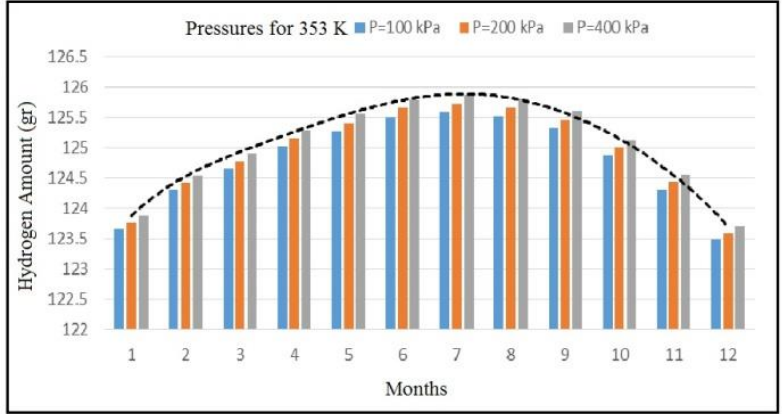

a

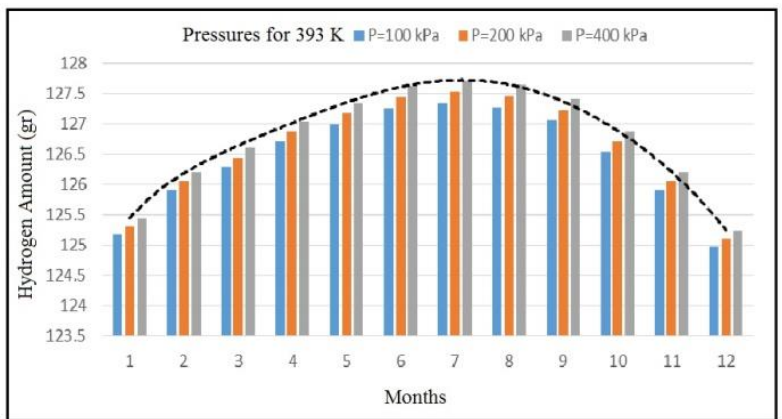

C

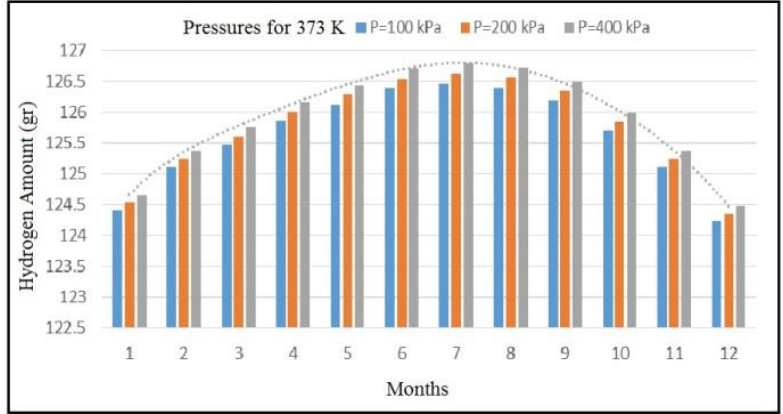

$\mathrm{b}$

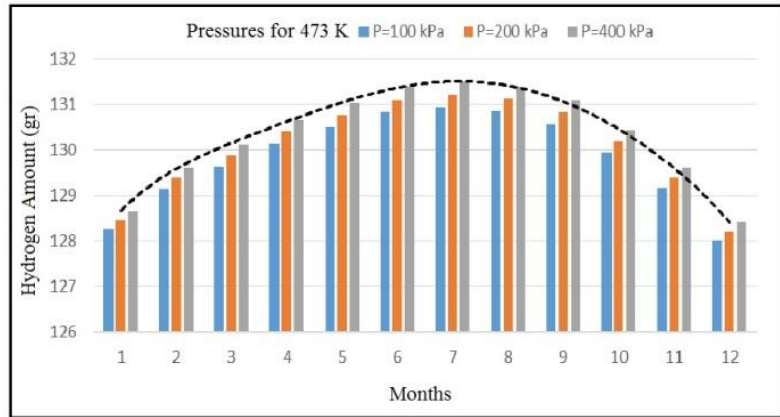

d

Figure 9. Generated hydrogen amount in the electrolyzer electricity consumption for fixed temperatures

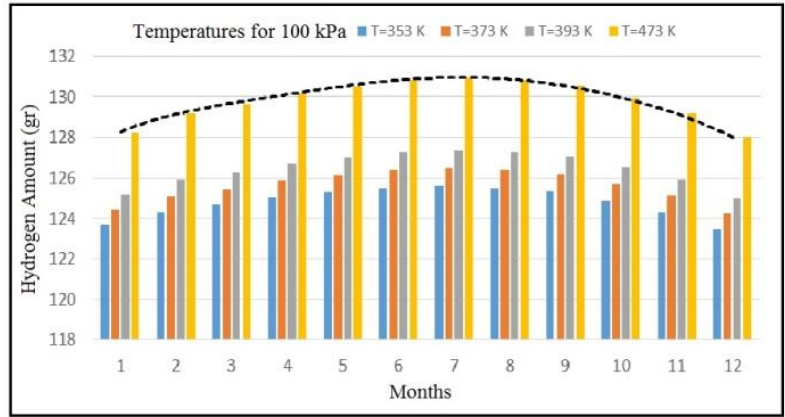

a

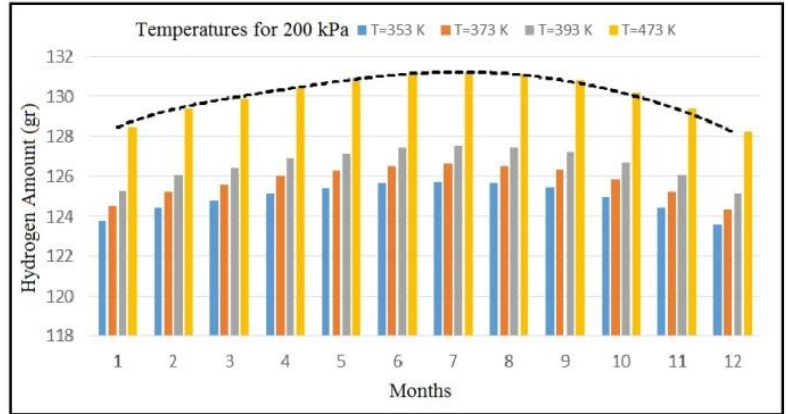

$\mathrm{b}$

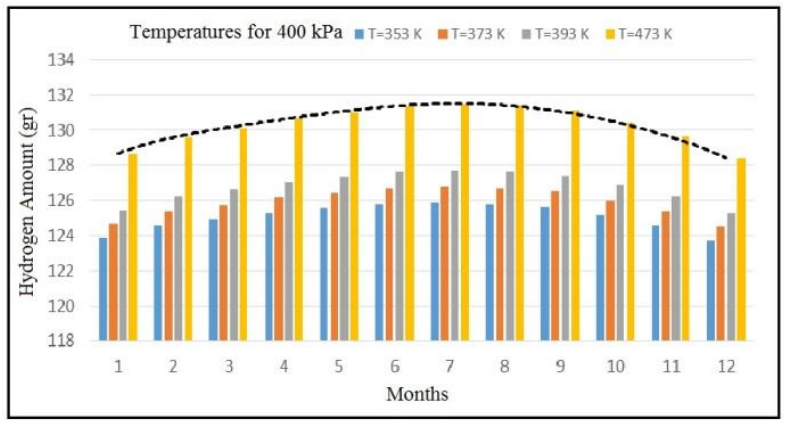

C

Figure 10. Generated hydrogen amount in the electrolyzer electricity consumption for fixed pressures

For the second part of the results section, three different hydrogen flow rate were selected for the simulation of PEM duel cell; namely 5.5, 8 and 11.2 Standard Liter per Minute (SLPM). 1.5 seconds time was taken as the simulation duration. Two magnitudes were monitored and presented here; the power of the PEM fuel cell in Watts and the output voltage in Volts. The response of the system is very fast so the time axis was plotted with logarithmic scale in order to ease reading. 


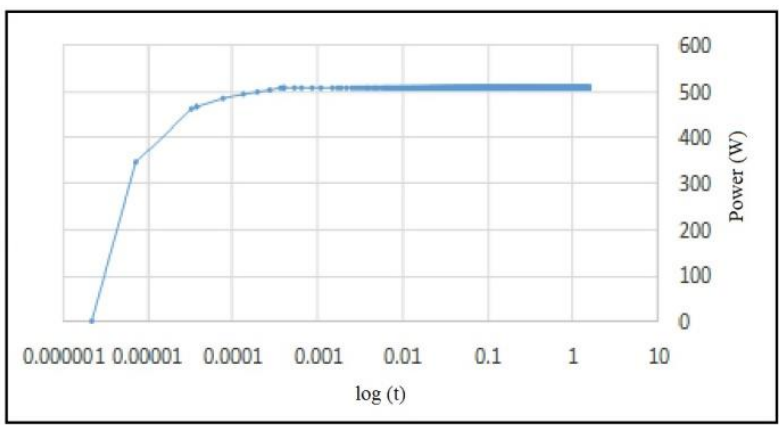

a -5.5 SLPM

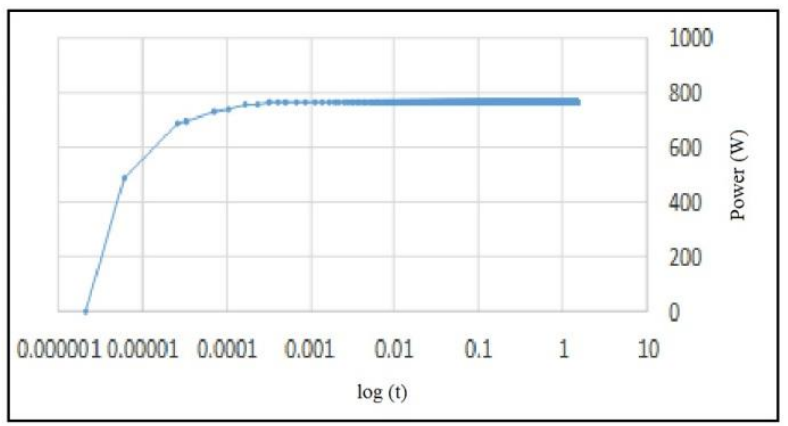

c-8 SLPM

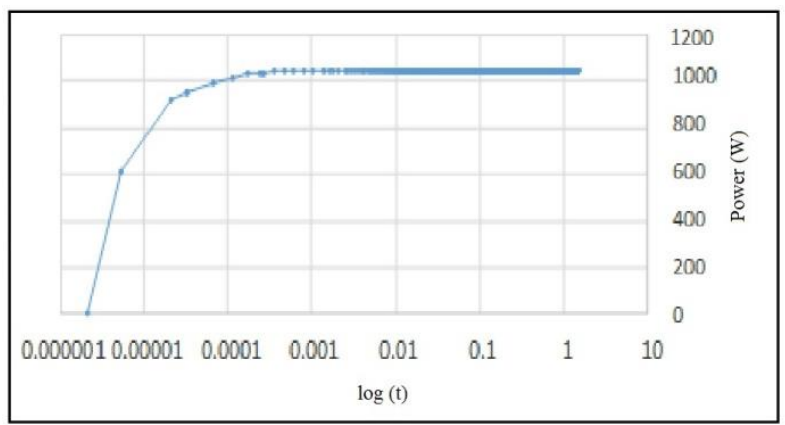

e - 11.2 SLPM

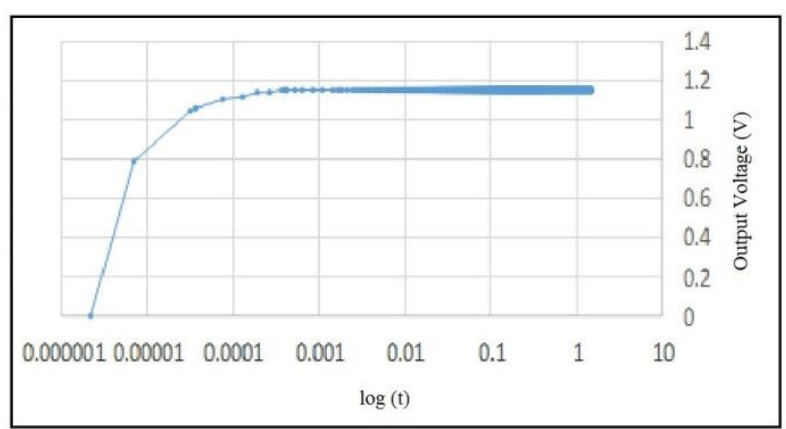

$\mathrm{b}-5.5 \mathrm{SLPM}$

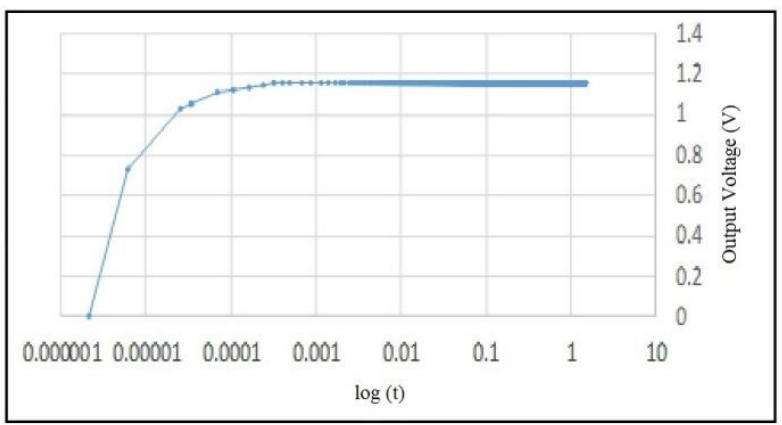

$\mathrm{d}-8 \mathrm{SLPM}$

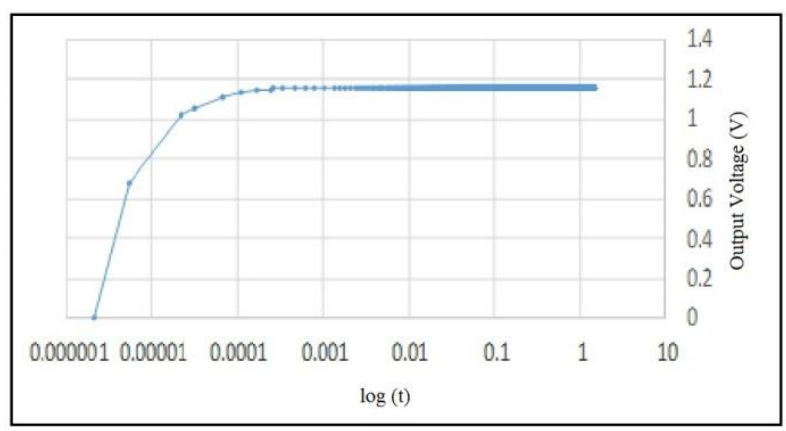

$\mathrm{f}-11.2$ SLPM

Figure 11. Fuel cell power curve on the left column and voltage curve on the right column

The modeled PEM fuel cell nominal power output is $500 \mathrm{~W}$. The DC voltage is $23 \mathrm{~V}$ and current is 22 A for this nominal output power. Although the maximum power of the PEM fuel cell is $1100 \mathrm{~W}$, the actual maximum is about $1000 \mathrm{~W}$ due to the internal resistances. DC voltage again can be taken as $23 \mathrm{~V}$ for this case. The obtained current in the other hand would be $45 \mathrm{~A}$. The hydrogen input for the $500 \mathrm{~W}$ power is 5.5 SLPM. The hydrogen input to the PEM is 11.2 SLPM for $1000 \mathrm{~W}$ power output. 8 SLPM was selected as an internal value and the power output for this flow rate is about $760 \mathrm{~W}$. The electrical current here is $33 \mathrm{~A}$.

After a very short time, namely between 0.0001 and 0.001 seconds, the PEM fuel cell reaches to 500 $\mathrm{W}$ and $1.159 \mathrm{~V}$ for $5.5 \mathrm{SLPM}$ flow rate of hydrogen. After this point, the system remains stable. For the 8 SLPM value, the power and voltage are $760 \mathrm{~W}$ and $1.159 \mathrm{~V}$ respectively for the same period. The response time is same for 11.2 SLPM with the previous flow rates while power output is $1000 \mathrm{~W}$.

\section{CONCLUSION}

An experimental energy generation system to be established in Konya is simulated in this study in order to achieve the main objective that is proposing a system design that can be used for avoiding intermittent characteristics of the solar energy by means of hydrogen storage. The results were acquired 
by means of MATLAB-SIMULINKTM and an in-house MATLAB code for the simulation which consists of electricity generation from PV panels, hydrogen generation by means of water electrolysis and using this generated hydrogen in a PEM fuel cell. Necessary graphics are plotted by using the results from the simulations.

Following conclusions can be drawn from the results.

- There is an electricity generation potential for the whole year and this potential reaches to a maximum during summer months which are June, July and August. The maximum power harnessed from the PV setup can reach to $1800 \mathrm{~W}$ at peak solar insolation months while the minimum amount is about $300 \mathrm{~W}$.

- The conversion efficiency of the PV system plays a crucial role for the system power output and determines the basic payback period of the system.

- Hydrogen production is increasing with increasing temperature in electrolysis unit.

- Temperature and pressure affect the unit energies by affecting Gibbs free energy and the entropy difference for the thermal energy input.

- The share of the electricity in the electrolysis process goes down with the increase in the thermal energy input to the electrolyzer.

- As an instance for the hydrogen production, $130.94 \mathrm{~g} / \mathrm{h}$ is generated in July for the $473 \mathrm{~K}$ and $100 \mathrm{kPa}$. For the $393 \mathrm{~K}$, the hydrogen production drops to approximately $127.5 \mathrm{~g} / \mathrm{h}$ and the remaining two values are $126.5 \mathrm{~g} / \mathrm{h}$ and $125.5 \mathrm{~g} / \mathrm{h}$ for $373 \mathrm{~K}$ and $353 \mathrm{~K}$ respectively.

- The chemical bonds between atoms in the molecules are weaker for the higher temperatures and Gibbs free energy required for the electrolysis is lower for the higher temperatures so the hydrogen generation at a high electrolyzer temperature is higher for a constant voltage and current. The energy that the electrolyzer uses is not increasing much with the increasing temperature or pressure.

- After a very short time between 0.0001 and 0.001 seconds, the PEM fuel cell reaches to $500 \mathrm{~W}$ and $1.159 \mathrm{~V}$ for $5.5 \mathrm{SLPM}, 760 \mathrm{~W}$ and $1.159 \mathrm{~V}$ for the 8 SLPM and $1000 \mathrm{~W}$ for 11.2 SLPM.

For the future work, following remarks can be given.

- The designed system in the context of this study can be regarded as an ideal energy generation system for the rural areas.

- The stored hydrogen can be directly used as a clean and renewable fuel while it can be used in a PEM fuel cell in order to generate electricity.

- The electrolyzer is not a pressurized vessel in the study. Hence, the generated hydrogen should be stored in a pressurized can by means of a compressor. If the electrolyzer device can be defined as a pressurized volume, PEM fuel cell can be used directly without utilizing an additional storage and compressor.

- Since hydrogen storage by pressurizing is considered, various electrolyzer design including pressurized ones can be considered to be utilized.

- In the presence of a financial support, this simulation can be compared with the results of an experimental setup.

- Simulation can be enhanced by modeling the assumptions or integrating some more real world data into the simulation.

As a general self evaluation of the present work, a considerable contribution to the specific literature and the field is done. Presented data and the method can be used directly in order to give reference to an idea or can be improved for a more detailed work. Real world data were used in order to provide inputs for the simulated system and this is one of the novel contributions to the literature. The potential of the region in terms of hydrogen generation and solar energy utilization can be assessed. Another important contribution of the present work to the literature is the survey and evaluation of the similar works in an extensively manner. By this way one can use this paper to assess the application with a wide 
perspective. The simulation presented here can be used in order to avoid costly trial and error approaches or in other words reduce the possibilities.

\section{ACKNOWLEDGEMENT}

The authors of this work would like to acknowledge the help and support of Selcuk University.

\section{REFERENCES}

Akyildiz, H., Öztürk, T., 2013, "Production of mg-Mased Amorphous/Nanostructured Thin Films from Multi-Elemental Sources for Hydrogen Storage Applications", J. Fac.Eng.Arch. Selcuk Univ., Vol. 28(1), pp. 1-10.

Ali, D., Gazey, R., Aklil, D., 2016, “Developing a Thermally Compensated Electrolyzer Model Coupled with Pressurized Hydrogen Storage for Modeling the Energy Efficiency of Hydrogen Energy Storage Systems and Identifying Their Operation Performance Issues", Renewable and Sustainable Energy Reviews, Vol. 66, pp. 27-37.

Allison, J., 2017, “Robust Multi-Objective Control of Hybrid Renewable Microgeneration Systems with Energy Storage", Applied Thermal Engineering, Vol. 114, pp. 1498-1506.

Amusat, O.O., Shearing, P.R., Fraga, E.S., 2017, “On the Design of Complex Energy Systems: Accounting for Renewable Variability in Systems Sizing", Computers and Chemical Engineering, Vol. 103, pp. 103-115.

Amphlett, J.C., Baumert, R.M., Mann, R.F., Peppley, B.A., Roberge, P.R., Harris, T.J., 1995, “Performance Modeling of the Ballard-Mark-Iv Solid Polymer Electrolyte Fuel-Cell: 1. Mechanistic Model Development", Journal of the Electrochemical Society, Vol. 142(1), pp. 1-8.

Bai, M., Song, K., Sun, Y., He, M., Li, Y., Sun, J., 2014, “An Overview of Hydrogen Underground Storage Technology and Prospects in China", Journal of Petroleum Science and Engineering, Vol. 124, pp. 132-136.

Baricco, M., Bang, M., Fichtner, M., Hauback, B., Linder, M., Luetto, C., Moretto, P., Sgroi, M., 2017, "SSH2S: Hydrogen Storage in Complex Hydrides for an Auxiliary Power Unit Based on High Temperature Proton Exchange Membrane Fuel Cells", Journal of Power Sources, Vol. 342, pp. 853-860.

Boudries, R., 2013, "Analysis of Solar Hydrogen Production in Algeria: Case of an ElectrolyzerConcentrating Photovoltaic System", International Journal of Hydrogen Energy, Vol. 38(26), pp. 11507-11518.

Ceraolo, M., Miulli, C., Pozio, A., 2003, “Modelling Static and Dynamic Behaviour of Proton Exchange Membrane Fuel Cells on the Basis of Electro-Chemical Description", Journal of Power Sources, Vol. 113(1), pp. 131-144.

Chong, L.W., Wong, Y.W., Rajkumar, R.K., Rajkumar, R.K., Isa, D., 2016, “Hybrid Energy Storage Systems and Control Strategies for Stand-Alone Renewable Energy Power Systems", Renewable and Sustainable Energy Reviews, Vol. 66, pp. 174-189.

Esquivel, J.P., Buser, J.R., Lim, C.W., Domínguez, C., Rojas, S., Yager, P., Sabate, N., 2017, “Single-use Paper-Based Hydrogen Fuel Cells for Point-of-care Diagnostic Applications", Journal of Power Sources, Vol. 342, pp. 442-451.

Fallisch, A., Schellhase, L., Fresko, J., Zechmeister, M., Zedda, M., Ohlmann, J., Zielke, L., Paust, N., Smolinka, T., 2017, "Investigation on PEM Water Electrolysis Cell Design and Components for a HyCon Solar Hydrogen Generator", International Journal of Hydrogen Energy, Vol. 42(19), pp. 13544-13553.

Fan, X.C., Wang, W.Q., Shi, R.J., Cheng, Z.J., 2017, “Hybrid Pluripotent Coupling System with Wind and Photovoltaic-Hydrogen Energy Storage and the Coal Chemical Industry in Hami, Xinjiang", Renewable and Sustainable Energy Reviews, Vol. 72, pp. 950-960. 
Gemmen, R.S., 2001, ASME International Mechanical Engineering Congress and Expositions, New York.

Gemmen, R.S., Farmouri, P., 2002, "Power Elekteronics for Fuel Cells Workshop", University of California, Irvine, National Fuel Cell Research Center.

Guida, D., Minutillo, M., 2017, “Design Methodology for a PEM Fuel Cell Power System in a more Electrical Aircraft", Applied Energy, Vol. 192, pp. 446-456.

Guo, K., Prevoteau, A., Rabaey, K., 2017, “A Novel Tubular Microbial Electrolysis Cell for High Rate Hydrogen Production", Journal of Power Sources, Vol. 356, pp. 484-490.

Guo, J., Xing, L., Hua, Z., Gu, C., Zheng, J., 2016, “Optimization of Compressed Hydrogen Gas Cycling Test System based on Multi-Stage Storage and Self-Pressurized Method", International Journal of Hydrogen Energy, Vol. 41(36), pp. 16306-16315.

Hu, K., Chen, L., Chen, Q., Wang, X.H., Qi. J., Xu, F., Min, Y., 2017, “Phase-change Heat Storage Installation in Combined Heat and Power Plants for Integration of Renewable Energy Sources into Power System", Energy, Vol. 124, pp. 640-651.

Izgi, M.S., Odemis, O., Sahin, O., Saka, C., 2016, "Effect of NaOH in Hydrogen Production from $\mathrm{NaNH}_{4}$ by using Co-B-F and Co-B-P catalysts", SUJEST, Vol. 4(1), pp. 55-64.

Jia, F., Guo, L., Liu, H., 2017, “Mitigation Strategies for Hydrogen Starvation under Dynamic Loading in Proton Exchange Membrane Fuel Cells", Energy Conversion and Management, Vol. 139, pp. 175181.

Kim, J., Lee, S.M., Srinivasan, S., Chamberlin, C.E., 1995, “Modeling of Proton Exchange Membrane Fuel Cell Performance with an Empirical Equation", Journal of the Electrochemical Society, Vol. 142 (8), pp. 2670-2674.

Kivrak, H., Demir, N.C., Sahin, O., 2013, “Electrocatalytic Properties of Nanostructured Multimetallic Pt$\mathrm{Sn}-\mathrm{Cs} / \mathrm{C}$ and $\mathrm{Pt}-\mathrm{M} / \mathrm{C}(\mathrm{M}=\mathrm{Ag}, \mathrm{Ca}, \mathrm{Cd}, \mathrm{Cs}, \mathrm{Cu}, \mathrm{Fe}, \mathrm{Ir}, \mathrm{Mg}, \mathrm{Pd}, \mathrm{Sn}, \mathrm{Zr})$ Direct Ethanol Fuel Cell Catalysts", Selcuk Univ. J. Eng. Sci. Tech., Vol. 1(2), pp. 19-28.

Kleiner, F., Posern, K., Osburg, A., 2017, "Thermal Conductivity of Selected Salt Hydrates for Thermochemical Solar Heat Storage Applications Measured by the Light Flash Method", Applied Thermal Engineering, Vol. 113, pp. 1189-1193.

Kumar, S., Jain, A., Ichikawa, T., Kojima, Y., Dey, G.K., 2017, “Development of Vanadium Based Hydrogen Storage Material: A review", Renewable and Sustainable Energy Reviews, Vol. 72, pp. 791-800.

Larminie, J., Dicks, A., McDonald, M.S., 2003, Fuel Cell Systems Explained, Wiley, New York.

Lashgari, M., Elyas-Haghighi, P., Takeguchi, M., 2017, “A Highly Efficient pn Junction Nanocomposite Solar-Energy-Material [nanophotovoltaic] for Direct Conversion of Water Molecules to Hydrogen Solar Fuel", Solar Energy Materials \& Solar Cells, Vol. 165, pp. 9-16.

Mamaghani, A.H., Najafi, B., Casalegno, A., Rinaldi, F., 2017, "Predictive Modelling and Adaptive LongTerm Performance Optimization of an HT-PEM Fuel Cell based Micro Combined Heat and Power (CHP) Plant", Applied Energy, Vol. 192, pp. 519-529.

Marr, C., Li, X., 1997, "An Engineering Model of Proton Exchange Membrane Fuel Cell Performance", ARI-An International Journal for Physical and Engineering Sciences, Vol. 50(4), pp. 190-200.

Mohamed, W.A.N.W., Kamil, M.H.M., 2016, “Hydrogen Preheating Through Waste Heat Recovery of an Open-Cathode PEM Fuel Cell Leading to Power Output Improvement", Energy Conversion and Management, Vol. 124, pp. 543-555.

Ngoh, S.K., Ohandja, L.A., Kemajou, A., Monkam, L., 2014, “Design and Simulation of Hybrid Solar High-Temperature Hydrogen Production System using both Solar Photovoltaic and Thermal Energy", Sustainable Energy Technologies and Assessments, Vol. 7, pp. 279-293.

Nieskens, D.L.S., Ferrari, D., Liu, Y., Kolonko R., 2011, "The Conversion of Carbon Dioxide and Hydrogen into Methanol and Higher Alcohols", Catalysis Communications, Vol. 14(1), pp. 111113.

Nojavan, S., Zare, K., Mohammadi-Ivatloo, B., 2017, "Application of Fuel Cell and Electrolyzer as Hydrogen Energy Storage System in Energy Management of Electricity Energy Retailer in the 
Presence of the Renewable Energy Sources and Plug-in Electric Vehicles", Energy Conversion and Management, Vol. 136, pp. 404-417.

Ostrovskii, V.E., 2002, "Mechanisms of Methanol Synthesis from Hydrogen and Carbon Oxides at $\mathrm{Cu}-$ Zn-containing Catalysts in the Context of Some Fundamental Problems of Heterogeneous Catalysis", Catalysis Today, Vol. 77(3), pp. 141-160.

Padin, J., Veziroglu, T., Shahin, A., 2000, "Hybrid Solar High-Temperature Hydrogen Production System", International Journal of Hydrogen Energy, Vol. 25(4), pp. 295-317.

Rzayeva, M., Salamov, O., Kerimov, M., 2001, "Modeling to Get Hydrogen and Oxygen by Solar Water Electrolysis", International Journal of Hydrogen Energy, Vol. 26(3), pp. 195-201.

Sayin, S., Koç, I., 2011, “Güneş Enerjisinden Aktif Olarak Yararlanmada Kullanilan Fotovoltaik (PV) Sistemler ve Yapılarda Kullanım Biçimleri", J. Fac.Eng.Arch. Selcuk Univ., Vol. 26(3), pp. 89-106. (in Turkish)

Shekardasht, S.J., 2016, An Investigation on Generation of Solar Powered (pv) and Applications in Hydrogen Fule Cells, MSc Thesis, Selcuk University Institute of Natural and Applied Sciences, , Konya TURKEY. (in Turkish)

Ural, Z., 2007, Yakıt Pilleri ve Bir PEM Yakıt Pili Sisteminin Dinamik Benzetimi, MSc Thesis, Dicle University, Institute of Natural Sciences.

Vincent, I., Kruger, A., Bessarabov, D., 2017, “Development of Efficient Membrane Electrode Assembly for Low Cost Hydrogen Production by Anion Exchange Membrane Electrolysis", International Journal of Hydrogen Energy, Article In Press, 1-10. (http://dx.doi.org/10.1016/j.ijhydene.2017.03.069)

Yu, X., Tang, Z., Sun, D., Ouyang, L., Zhu, M., 2017, “Recent Advances and Remaining Challenges of Nanostructured Materials for Hydrogen Storage Applications", Progress in Materials Science, Vol. 88, pp. 1-48.

Zhang, L., Zhu, X., Cao, Z., Wang, Z., Li, W., Zhu, L., Li, P., Huang, X., Lü, Z., 2017, “Pr and Ti co-doped Strontium Ferrite as a Novel Hydrogen Electrode for Solid Oxide Electrolysis Cell", Electrochimica Acta, Vol. 232, pp. 542-549.

Zhong, H., Ouyang, L.Z., Ye, J.S., Liu, J.W., Wang, H., Yao, X.D., Zhu, M., 2017, “An One-step Approach Towards Hydrogen Production and Storage Through Regeneration of $\mathrm{NaBH}_{4}$ ", Energy Storage Materials, Vol. 7, pp. 222-228.

Ziogou, C., Voutetakis, S., Papadopoulou, S., Georgiadis, M.C., 2011, "Modeling, Simulation and Experimental Validation of a PEM Fuel Cell System", Computers \& Chemical Engineering, Vol. 35(9), pp. 1886-1900. 